\title{
Organizations as Place Builders
}

\author{
David F. Thomas \\ University of Northern Colorado \\ Jennifer E. Cross \\ Colorado State University
}

\begin{abstract}
We argue that the role of organizations as agents in the construction of place has been overlooked in the management and organizations literature. Using concepts from sociology, cultural geography, and management, we develop a typology that illustrates how organizations contribute to the social construction of place. This typology presents an analytic scheme for examining the place-building characteristics of organizations and a basis for developing theories on the interdependence between places and organizations.
\end{abstract}

\section{Organizations as Place Builders}

In the past two decades, the concept of place has garnered increasing attention across many disciplines. Since place has become a widely used concept, scholars have become increasingly sensitive to the ways it is utilized in research. Over the past decade, sociologists have pointed out the need for researchers to make explicit their assumptions about place, to be more place-sensitive, and to treat place as agents in social phenomena (Agnew, 1993; Gieryn, 2000; Werlen, 1993). They argue that sociology has too often treated place in reductionistic ways, as a simple independent variable or backdrop to social action, rather than intertwined with other social processes (Gans, 2002; Gieryn, 2000).

This critique of social science applies also to management and organizations literature, where place is typically considered the backdrop for organizational practices, treated in reductionistic ways, or simply ignored. In the management literature, place has been traditionally limited to the study of organizational climate and employee commitment or productivity in a given space, such as a building or work place environment (Denison, 1996; Ouchi and Wilkins, 1985; Guion, 1973; and Jams and Jones, 1974; Guzzo, R.A., 1996). Instead of being informed by the growing literature on place, use of the concept in the organization's literature has not advanced beyond considerations of organizational climate, attachment, and affiliation (Hudson, 2001; Sagoff, 1996; Schoenberger, 1997; Wright, 1994).

Herbert Gans has recently argued that the current challenge for social scientists who study space and place is to examine the causal relationships between space and society without reifying space or simply confirming the obvious fact that society exists in 
space (2002: 329). He contends that researchers should be focusing their efforts on the ways in which individuals and collectivities turn natural space in social space and shape its uses. In this article, we take up this challenge by examining how organizations, a particular type of collective, shape places through the full range of their values and behaviors. In so doing, we propose a new definition of corporate social responsibility (CSR), one that defines corporations as agents, whose actions, values, behaviors, and strategies contribute in myriad ways to the social construction of places. This nascent view of CSR emerges from an interdisciplinary outlook that broadens CSR to include the complete array of a corporation's actions.

CSR is defined in numerous ways with some definitions being narrower than others. In its most basic definition, CSR is associated with a narrow scope of activities that may benefit communities, but are intended primarily to protect or enhance highly visible brands or reputations (Vogel, 2005). CSR has often been simplistically defined as a synonym for philanthropy (Kotler \& Lee, 2005; McClenahen, 2005). A more comprehensive definition of CSR argues that social responsibilities must be integrated into all aspects of business and is marked by a commitment to improve community wellbeing through business practices and corporate resources (Kotler and Lee, 2005). Another definition of CSR suggests that it includes the act of making long-term commitments to social issues, initiatives, and forming strategic alliances (Smith, 1994). Our intention in this article is to expand the conceptual tools available for theorizing about the causal influence of organizational strategies and behaviors on the places in which they are located. Towards that end, we propose a typology of organizational orientations and strategies that differentiate the ways organizations participate in the social construction of place. Fundamentally, we believe that examining organizations as "place builders" is timely and important to both organizations and communities.

In this article we do three things. First, we review the literature on the social role of corporations and the concept of place as a social construction. Second, we propose a typology of organizational priorities and behaviors that characterize how a corporation's actions contribute to the social construction of place. We use the common definition of place-a meaningful location or site (Creswell, 2004). Third, we examine the causal relationship between a corporation's actions and the dynamic process of place construction.

\section{Social Role of Organizations}

When the relationship between an organization and place is discussed, it is primarily addressed in terms of corporate social responsibility (CSR) and corporate citizenship. Before laying out a model for understanding how organizations act as "place builders", we review the literature on corporate social responsibility in order to discuss current conceptions of the relationships between places and corporations. Although we recognize that corporations and organizations are different in many respects and we will be using only corporations as illustrative examples, we will use the terms corporations and organizations interchangeably as our model applies to both. 
CSR has blossomed into a growing scholarly literature and public discussion. Nevertheless, no single objective method has emerged which corporations and their stakeholders might use to evaluate the level or extent of a corporation's social responsibility, its intentions, and more importantly its contributions (Hopkins, 1999). Hopkins (1999) points to a list of items that might define or measure CSR; among them is profitability, tax contributions, socially responsible projects and operations, philanthropic contributions, good working conditions, support of social investments and the like. Kotler and Lee (2005) have identified philanthropy as only one of five major activities typically described as CSR. The other four are: cause promotions, causerelated marketing, community volunteerism, and business practices. As we will discuss later, each of these activities is a significant piece of an organization's role as agent in place building. McClenahen has described how corporate philanthropy is capable of producing some tangible social and environmental benefits (2005); however, corporate philanthropy is only a small portion of an organization's activities.

Enterprises have noted that CSR is good for business and for each group of shareholders and the places within which they operate. Research has shown that positive contributions that grow and sustain a place are likely to have positive effects on profitability and return on investment (Vogel, 2005). Conversely, poor internal humanresource policy, cavalier downsizing, an industrial caused environmental disaster or conviction for a corporate crime are to likely have harmful effects (Hopkins, 1999; Anderson, 1989; Cooper, 2004).

More general literature on the role of organizations as agents focuses primarily on organizations as fiduciary agents with legal responsibilities to their shareholders and stakeholders. This view of organizations as fiduciary agents limits the scope of their responsibilities to economic vitality and legal mandates (May, 1983). Anderson (1989) posits that "CSR involves a legal responsibility (complying with the law), setting-and abiding by-moral and ethical standards, and philanthropic giving" (p.9). Further, he defines CSR as "the obligation of both businesses and society (stakeholders) to take proper legal, moral-ethical and philanthropic actions that will protect and improve the welfare of both society and business as a whole; all of this must of course be accomplished within the economic structures and capabilities of the parties involved" ( $p$. 9).

In recent decades, policy makers and social scientists alike have critiqued liberalism for its overemphasis on individual freedom and neglect of communal responsibilities (Etzioni 1993, Hopkins 1999). Tony Blair (as cited in Hopkins, 1999) posits that:

[L]egislation could not guarantee that a company will behave in a way conducive to trust and long-term commitment. Companies should shift their notion of their legal responsibilities to one of community partner in which each employee has a stake and where a company's responsibilities are clearly stated. (p. 13)

This notion that companies ought to expand their conception their responsibilities beyond fiscal responsibility to shareholders and basic legal responsibilities to the state 
parallels the communitarian argument that individuals and groups both act as agents influencing society, and thus must also recognize their responsibilities to individuals, institutions, and society (Selznick 1995, Etzioni 1998). The question is not whether a company should practice socially responsible behavior, but rather how deeply a company should become involved and invested in the places in which they operate. As Cooper states "organizations more generally should be held accountable to the society within which they operate" $(2004,62)$. It is time to look beyond the landscape of CSR as a legal responsibility and philanthropic duty to a new horizon that views the corporation as an agent that invests its resources in its community as place and not as control in or over its community.

This expanded conception of CSR fits with recent work by scholars who have expanded the literature to examine the interactions between organizations and places (Black and Hartell, 2004; Newell, 2005; Langtry, 1994). Any useful framework to guide CSR practices and philanthropy must address the specific interactions between a business and the social conditions in which the organization operates. It is not enough to say an organization is doing well because one or more of their philanthropic acts has resulted in tangible results. To this end, we have seen the emergence of a number of management models that help businesses find new ways to respond to the unforeseen challenges and demands of a society in transition (Jonker and de Witte, 2006).

The triple bottom line typology has gained wide-spread recognition as a valuable tool in helping organizations position CSR into their regular operations (Savitz and Weber, 2006). Other models like the Integrated Management model (Jonker and Witte, 2006) provide a generic approach to linking all organizational aspects of CSR. The Molecule model (Folkerts and Weijers, 2006) is designed to help firms integrate the concept of sustainable development into their strategies and operations for societal and corporate development.

The Global Compact Performance model (Fussler and van der Vegt, 2004) provides efficient and effective strategies for making operational changes in order to improve a firm's CSR. These models are evidence that organizations are exploring new tools to help them integrate CSR in their strategies and daily operations. Our typology mirrors the intentions of these models in that we propose that all the activities of the organization contribute to the building of place. What we are proposing is a comprehensive examination of a corporation's actions and their influence on the places in which they are situated.

The intention of this article is to take the literature on place and apply that knowledge to organizations, in order to offer an external view of the consequences of organizational behavior. We are not making any suggestions about what organizations should be doing (injunctive norms), rather we examine what they are doing (descriptive norms) and categorize those from an external rather than an internal frame. We are not concerned here with the intentions or motivations of the organizations, per se, but rather we are concerned with their stated priorities and the consequences of their actions in relationship to places. 


\section{Social Construction of Places}

Studies of place begin by distinguishing between space and place. Space is made up of the natural and man-made material world, and is transformed into place when imbued with meaning through individual, group, or cultural processes (Altman \& Low, 1992; Creswell, 2004). As Tuan (1977) states, "space becomes place when it is endowed with meaning. And in so doing a commitment to that place is made on both an emotional and physical level" (p. 6). Places take on the meaning of events that occur there, and their descriptions are fused with human goals, values and intentions. Place is therefore not merely a phenomenon that exists in the minds of individuals but that develops from and becomes part of everyday life and experiences. The ordinary routines of life produce places that are meaningful, sacred and special to individuals, their organizations, and their communities (Williams, 1998).

Place, then, is defined as both geographical and social, and is organized around the meanings individuals and groups give to a place in its setting (Rodman, 1992). Place is not synonymous with community, though many people use the word community to indicate a place, the people who live and work there, their interactions with each other, and their attachment to that place. Community is one of the most overused and vaguely defined concepts in sociology, used to mean everything from a geographic place, to a group of people with common interests, to a sense of belonging in a group (Day 2006). In this paper use of the word community is limited to referencing ideas expressed by others about their conceptions of social responsibility when it connotes a geographical place including the people and social relationships that occur within that place.

Two premises underlie the assertion that place is a social construction. First, individuals are agents in the world, free to make meaning from their environment in ways that will contribute to the construction of place. Entrikin (2000) sees our ability to "socially construct" places as the result of our freedom to create meaning (p. 6). Finding meaning in space is both an individual and group process where humans act towards a place based on the meanings they have associated with that place; place requires human agency (Sack 1998).

Second, the meanings of a place are derived from or arise out of the interaction individuals and groups have with others in that place (Tuan, 1977). As Blumer posits, "the simple premise that human beings act toward things on the basis of the meaning of things is much too simple (1969, p.10)", suggesting that there is more to consider when identifying how place creates meaning. The meaning of place for a group or individual rises out of the ways in which people act toward each other with regard to that place (Blumer, 1969). The notion that places evolve from the interaction rather than simply geography, is described as early as 1925 by Carl Sauer in The Morphology of Landscape, and in a variety of more contemporary writings (Gustafson 2005, Sack 1997, Zelinsky 1992). For example a place could be defined as a tourist attraction, a sacred religious site, a natural wonder, or a wilderness site and each of these definitions of place suggest different interactions between people and the place as well as between 
individuals and groups within that place. The actions of individuals in a place simultaneously shape place and are guided by the meanings they form through interaction with individuals, groups, and organizations in that place.

\section{Realms of Place}

Researchers agree that place is a multi-dimensional concept including the natural world, the built environment, social relationships, economic relationships, patterns of interaction, as well as socially constructed meanings about each dimension; however, the models they offer for helping us to understand these dimensions vary. Geographer Robert Sack identifies the dimensions of place as including nature (synonymous with space), social relations (the economy, political institutions, families, etc.) and meaning (perceptions and theories of the other two realms) (1997, p. 28). Per Gustafson (2005) found that the meanings associated with places revolve around three primary themes, self, others, and the environment, which includes both the built environment and the natural world (p. 10).

Drawing on these two models of place, we have diagrammed the three realms of place that are particularly relevant to our discussion here, the material environment, the natural environment, and social relations (see Figure 1). Layered over the top of these three realms is meaning. Our model is similar to the model proposed by Sack, with the addition of one realm, the material environment. Nature includes the natural-as opposed to man-made-elements, forces, and spaces. These include the rocks and trees, hills and valleys, wind and rain, climate and gravity ${ }^{1}$.

Social Relations is the realm of human interaction, which includes the full spectrum of interactions between people whether between strangers, family members, or coworkers. Interactions form the building blocks of this realm. This realm includes not only the interactions between individuals and groups but also includes the social context of those interactions as well as lasting patterns of interaction such as family dynamics, inter-agency collaboration, and group conflicts. 


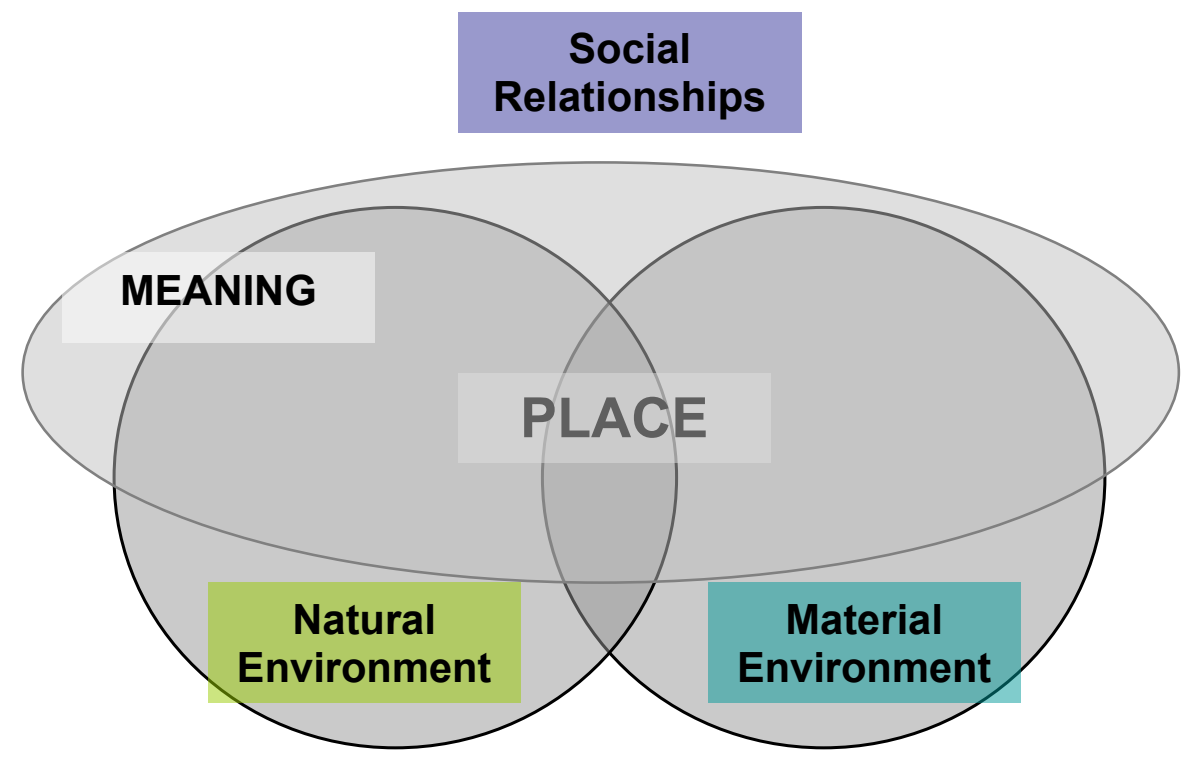

Figure 1. Realms of Place

The Material Environment includes both the economy as well as the built environmentman-made buildings, roads, and other structures. Whereas, Sack (1997) defines economic relationships as being part of the social relations realm, we see the economy as conceptually distinct from other social relations and patterns of interaction. Especially because we are interested in the economic activities of corporations, adding the material environment as a distinct realm allows us to discuss the relationship between aspects of the material environment and the other realms of place with greater conceptual clarity. In this article, we will focus our attention on how organizations contribute to each of the three realms-nature, social relationships, and the material environment-as well as the meanings associated with places and the relationships between realms. 


\section{Organizations as Place Builders}

We posit four qualitatively different types of organizations, each of which value place in unique ways, and therefore vary in how they contribute to or detract from the social construction of place. These four types of organizations are divided into two groups based on their conception of themselves as agents, which we have named their agent perspective. A corporation's agent perspective shapes its goals and values, then determines their corporate mission. Taken together, an organization's conception of them self as an agent and its mission determine its actions in regards to each realm of place thereby defining how each organization influences the construction of place.

\section{$\underline{\text { Two Place Perspectives }}$}

An organization's agent perspective distinguishes two distinct viewpoints held by organizations, which encompass not only how corporations conceptualize themselves in relationship to place, but also the meaning they give to place, which then influences their goals, contributions to place, and all variety of their behavior. We identify two types of agent perspectives; one perspective conceptualizes corporations and their success as interdependent with the well-being of place, and another which conceptualizes corporations and their success as independent of place (see Figure 2). Organizations with the interdependent perspective view themselves as members of a community and recognize that corporations and places are mutually dependent on each other. Interdependent organizations consider themselves responsible for the well-being of all three realms of place, view their success as intimately tied with the greater well-being of the place, and actively seek a variety of opportunities to invest and contribute to the multiple aspects of place. In contrast, organizations with an independent perspective, view themselves merely as occupants of place and economic agents, rather than integral members of place. Organizations that see themselves as independent agents focus their activities on satisfying internal goals while viewing the realms of place as resources to satisfy their needs. Their primary responsibility is to their shareholders, not the places in which they do business. They consider generating jobs and tax revenues as their primary, if not their only, contribution to place. Independent organizations are not committed to the well-being of place and will only maintain the relationship as long as it benefits their shareholders. 


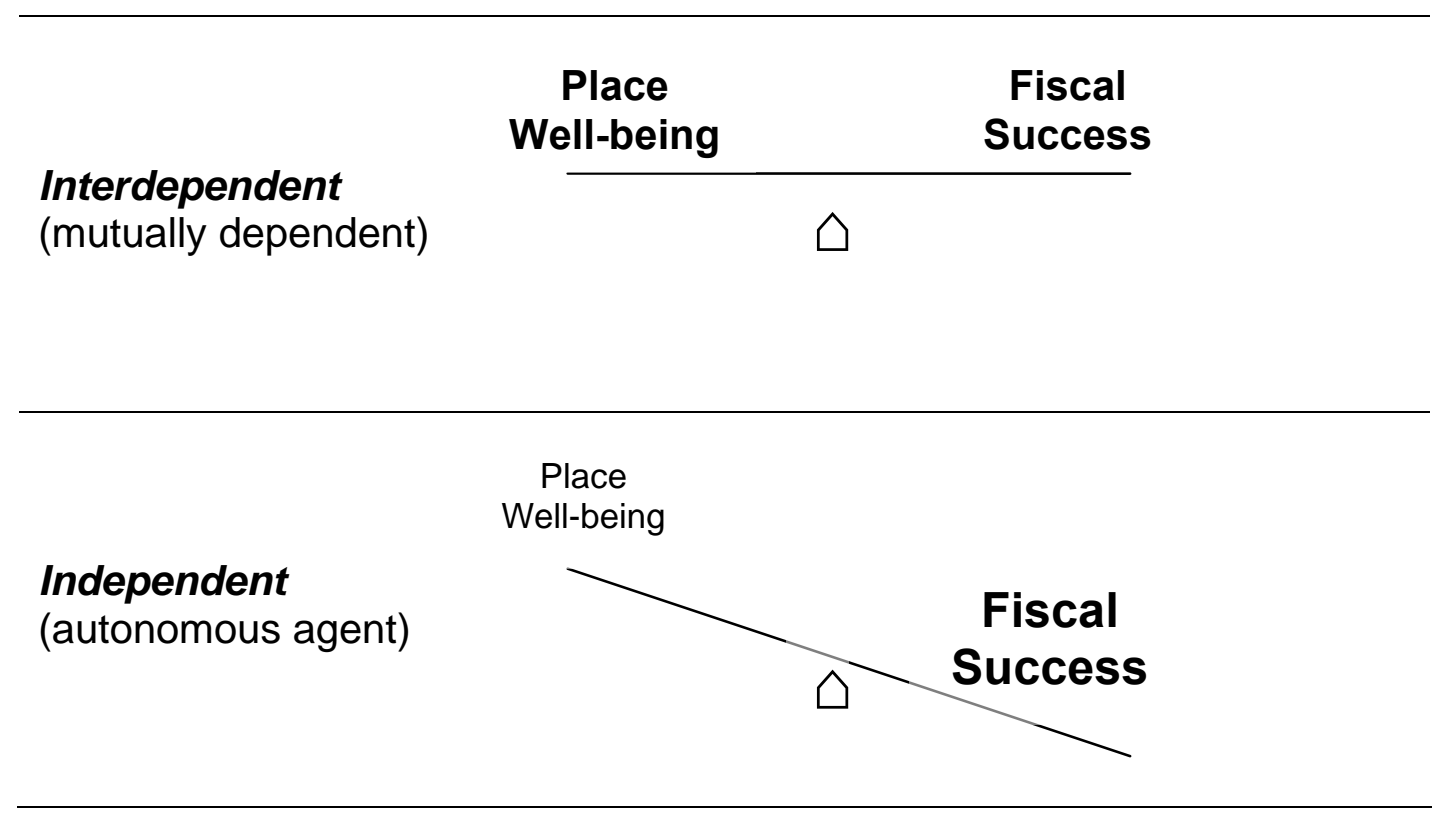

Figure 2. Two Types of Agent Perspectives

Within the two agent perspectives, we identify four distinct place agent identities, transformational, contributive, contingent, and exploitative. Place agent identities reveal how organizations conceptualize themselves as social actors-agents-in relation to the places in which they are located and do business. The four types of organizations differ in how they conceptualize themselves as agents, the value they assign to the realms of place, their corporate culture, and their strategies and behaviors. Transformational organizations conceptualize themselves as change agents acting to improve the lives of individuals and groups in a place. Contributive organizations conceptualize themselves as investors and contributors to the well-being of places in which they operate. Contingent organizations view themselves simply as participants in places and exploitative organizations view themselves as independent agents with little to no obligations to the places in which they operate.

Place agent identities are associated with particular values of place and are reflected in corporate culture as well as in their corporate behaviors and strategies (Table 1). One significant aspect of corporate culture is the value given to place. Interdependent and independent agents have distinctly different views on the value of place. Those with an interdependent perspective value places for their intrinsic worth while those with an independent perspective view places as commodities or resources to be utilized. 
Table 1. Organizations as Place Builder

\begin{tabular}{|c|c|c|c|c|c|}
\hline & $\begin{array}{l}\text { Place Agent } \\
\text { Identity }\end{array}$ & Value of Place & Cultural Characteristics & Behavior & Strategy \\
\hline Transformational & $\begin{array}{l}\text { change } \\
\text { agents }\end{array}$ & $\begin{array}{l}\text { cultural and } \\
\text { environmental } \\
\text { entity, } \\
\text { interdependent } \\
\text { systems } \\
\end{array}$ & $\begin{array}{l}\text { team-focused, } \\
\text { collaboratively minded, } \\
\text { values shared learning }\end{array}$ & $\begin{array}{l}\text { invest cultural and } \\
\text { economic } \\
\text { resources towards } \\
\text { the well-being of } \\
\text { place }\end{array}$ & $\begin{array}{l}\text { to orchestrate } \\
\text { organizational and } \\
\text { place well-being, } \\
\text { community } \\
\text { collaboration }\end{array}$ \\
\hline Contributive & $\begin{array}{l}\text { investors, } \\
\text { contributors }\end{array}$ & $\begin{array}{l}\text { social network, } \\
\text { resource }\end{array}$ & $\begin{array}{l}\text { community supporters, } \\
\text { philanthropic/benevolent, } \\
\text { paternalistic }\end{array}$ & $\begin{array}{l}\text { give to place via } \\
\text { fundraising, } \\
\text { sponsorship, and } \\
\text { leadership without } \\
\text { a specific } \\
\text { accounting of how } \\
\text { it benefits the } \\
\text { organization }\end{array}$ & $\begin{array}{l}\text { to participate in } \\
\text { achieving place } \\
\text { goals that build } \\
\text { social and cultural } \\
\text { capital which are } \\
\text { consistent with the } \\
\text { organizational } \\
\text { mission }\end{array}$ \\
\hline Contingent & participants & $\begin{array}{l}\text { social, } \\
\text { geographic, and } \\
\text { economic } \\
\text { commodity }\end{array}$ & competitive, instrumental, & $\begin{array}{l}\text { instrumental giving } \\
\text { to place is based } \\
\text { on specific and } \\
\text { identifiable benefit } \\
\text { to organization }\end{array}$ & $\begin{array}{l}\text { to participate in } \\
\text { achieving place } \\
\text { activities/events } \\
\text { that satisfy an } \\
\text { organization's } \\
\text { investment }\end{array}$ \\
\hline Exploitative & $\begin{array}{l}\text { independent } \\
\text { agents, } \\
\text { industry- } \\
\text { centric }\end{array}$ & $\begin{array}{l}\text { social, } \\
\text { geographic, and } \\
\text { economic } \\
\text { commodity }\end{array}$ & $\begin{array}{l}\text { profit-oriented, } \\
\text { manipulative, arrogant } \\
\text { ignorance }\end{array}$ & $\begin{array}{l}\text { exploit } \\
\text { environmental, } \\
\text { human, and } \\
\text { cultural capital for } \\
\text { corporate profit, } \\
\text { limited giving } \\
\text { (financial \& } \\
\text { volunteerism) to } \\
\text { local organizations }\end{array}$ & $\begin{array}{l}\text { to achieve } \\
\text { organizational } \\
\text { goals at the } \\
\text { expense of place }\end{array}$ \\
\hline
\end{tabular}


As the management literature has taken up the idea of culture, it has emphasized a fairly consistent set of themes and problems. Schoenberger (1997) posits "Corporate culture is generally viewed as a set of social conventions embracing behavioral norms, standards, customs, and the rules of the game underlying social interactions within the firm" (p. 113). On one level organizational culture refers to values that are shared by the people in a group and tend to persist over time (Kotter and Heskett, 1992) or as a concept that refers to how the company manages problems, and practices imposed by management (Wright, 1994) that can to some extent improve its ability to respond to global competition.

Corporate and organizational culture is a set of commonly shared values and beliefs which influences the behavior of people, including work and business practices (Hatch, 1993) and the total way of thinking, feeling, and behaving Kluckhohn (as cited in Geertz, 1973). These perspectives then guide an organization's strategies and behaviors in a place, thus shaping not only its own economic vitality, but also the development of place.

We agree with Smircich (1983, pg. 19) who argues that "culture is a process-it cannot be fixed onto a checklist of attributes of a delineated group: that would be to treat culture as a thing". Once you adapt this root metaphor for 'organizations as culture' we leave behind the view that culture is something an organization has, in favor of the view that a culture is something an org is (Smircich, 1983; Morgan, 1997). From this point of view of organization as culture, we avoid the positivistic models of culture and instead build on the deeper, more complex anthropological and social constructivist models. Culture will be most useful as a concept if it helps us better understand the hidden and complex aspects of how place is created through the meanings and interactions of multiple actors. Simply put, one cannot talk about space and its use which we believe leads to place making, if we are limited to the traditional concepts (Schein, 1992).

This dialectic nature of place making and culture is a key construct for organizational leaders in organizations of all size, but in particular to those who are responsible for guiding their organization in new arenas of global competition. Treating culture as a political and social process provides a theoretical approach for examining organizations as place builders. This approach helps avoid conceptualizing organizations as bounded units and focuses instead on organizations as cultural settings within ideological and material relationships. In other words, as Schoenberger (1997, pg. 121) would concur, that culture is really about "creating a way of life both in the organization and in the community in which it lives" (pg. 121). We are saying that humans, through their organizations, its social interactions and relationships, actually produce culture while culture is producing them and their organization. The notion that culture is constitutive strongly supports the notion that place creates the culture in which people interact with their environment in ways that are meaningful to them and by extension to the organization.

Each of the four types of organizations (transformational, contributive, contingent, and exploitative) create corporate missions which demonstrates different levels of 
commitment to place well-being and fiscal success. Organizations with the same agent perspective, but different agent identities, develop similar, although, not identical missions and strategies, which includes similar commitments to place well-being and/or fiscal success. Organizations with an interdependent perspective strive for a relatively equal balance between place well-being and their own fiscal success, whereas those organizations with an independent agent identity put much more emphasis and weight on fiscal success with little concern for place well-being. Figure 3, illustrates the minor differences between organizations that share the same agent identity, but distinct differences between organizations with different agent identities.

\section{Corporate Mission \& Priorities}

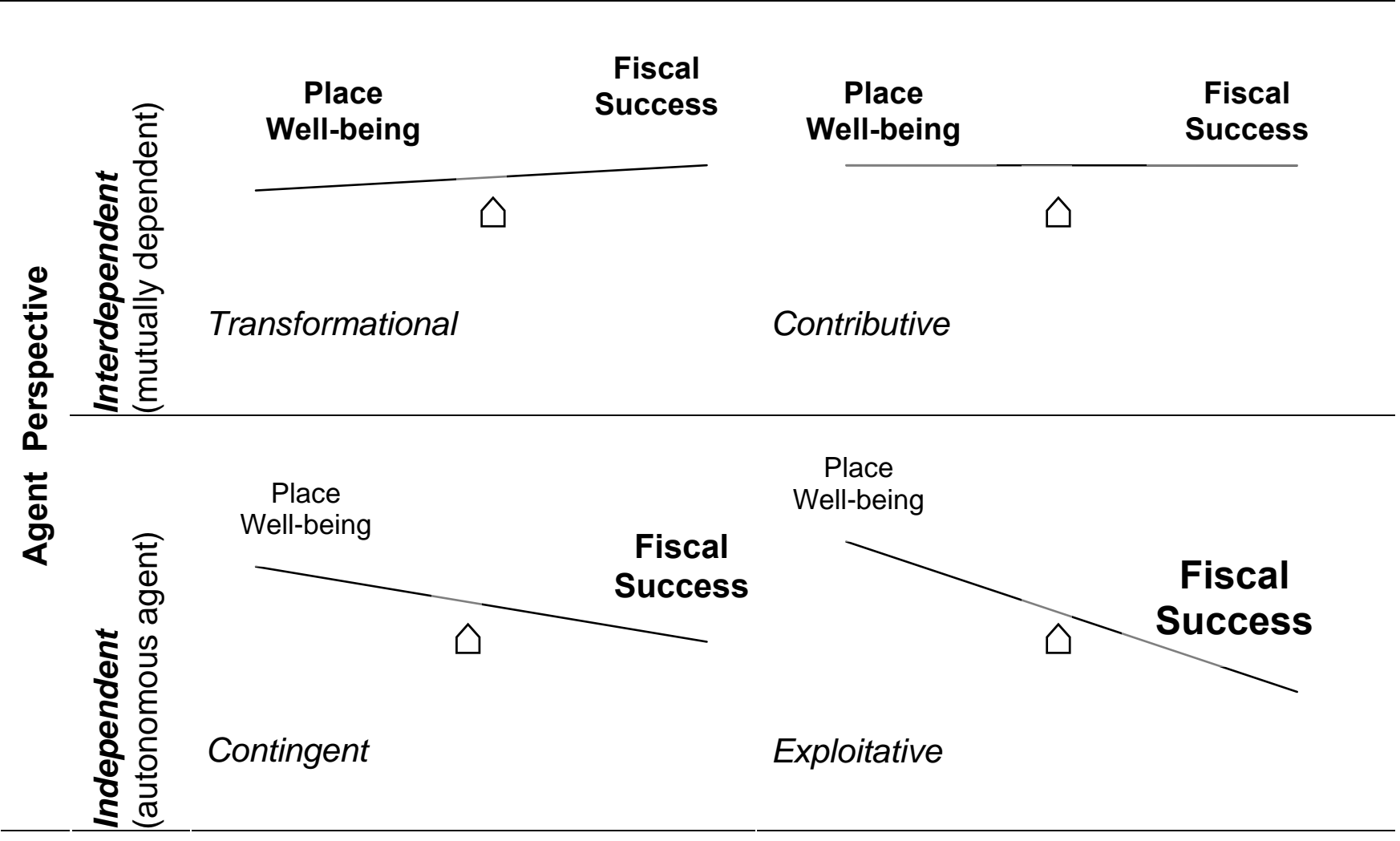

Figure 3. Four Types of Place Builders and Their Corporate Priorities

Corporations that conceptualize themselves as mutually dependent on place, develop missions which integrate and seek to balance place well-being and corporate fiscal success. These organizations utilize an integrative strategy, which focuses on fosteringand incorporating its resources in ways that help improve and/or change place. In contrast, those organizations that consider themselves independent of place develop missions that emphasize corporate fiscal success over place well-being. These organizations practice a separatist strategy, which focuses on the organization's access to and use of local resources. When comparing organizations that share the same 
agent identity perspective, there are minor differences in the degree to which they balance place well-being with fiscal success. It is these differences that distinguish the four types of organizations, transformational, contributive, contingent, and exploitative.

\section{Four Types of Place Builders}

To develop these four types, we will describe four different companies operating in the western United States ${ }^{2}$. We present these companies not because they are representative of all companies in the region or nation, but because they illustrate radically different types of corporate agents: transformational, contributive, contingent, and exploitative (see Table 1). As such, they provide concrete cases through which to explore the range of ways in which companies intentionally and unintentionally contribute to or detract from the material, social, and natural realms of place and their symbolic meanings.

\section{$\underline{\text { Transformational Organization }}$}

Transformational organizations are characterized by viewing themselves as a critical agent for change in the community. They hold an interdependent perspective and have corporate missions which focus on improving life and creating positive change for both the organization and the place. Their organizational cultures are highly focused on team learning, collaboration, and openness to change and building partnerships (Table 1). Members of transformational organizations have developed the skills and mind-sets that embrace their philosophy and attitudes of learning and teaching clients. These organizations value place as a cultural and environmental entity made up of unique social relationships, material relations, and natural resources and characteristics. They think of themselves of as members of that place, not separate from it. Because transformational organizations see themselves as part of an interdependent system, their success contributes to the success of the place, and vice versa. They practice an integrative strategy that focuses on creating and orchestrating a shared vision for the community and the organization which holds itself accountable to the community for the quality and content of its contribution to place. Transformational strategies and behaviors include initiating new policies and business practices for protecting the natural environment, neighborhoods, cultural heritage, local economy, and other local resources. Often these behaviors are a cost to the firm, are ahead of industry trends and regulation, and are not intended to create a public relations advantage.

World Partners. World Partners is a mid-sized company specializing in integrated real estate services. The organization has been operating since the 1960 s and employs approximately 150 people. The organization is an innovator in construction and architecture design. They combine both of these for the purpose of creating buildings that reflects the value of the community and the client, as well as transforming the construction industry. These practices have earned them regional and national recognition as a leader in advancing new technologies, safe-guarding the environment, and enhancing place. 
This organization exemplifies the transformational type in several ways. First its mission is distinguished from typical mission statements because it includes the well-being of its clients and community as well as the organization's fiscal well-being. World Partner's mission is to "significantly improve the economic vitality of our clients business and improve the lives of all that we touch to such a degree that it transforms the industry of the built environment, one project at a time". The language of this organization's mission statement is unique because it extends beyond organizational goals and specifically identifies which realm of place (the built environment) they intend to positively impact. This explicit mission to help improve the lives of others, is a bit didactic, like the corporate missions of noteworthy companies such as Cadbury which explicitly aimed to foster self-improvement (Dellheim 1986).

Second, this organization does more than design buildings; it partners with clients in designing buildings that meet the needs of the client, the larger place, and local stakeholders. For example, they have worked with local school districts to assess local needs and design buildings within budget and are compatible with local needs and values. By working closely with clients they change their own business practices to best meet client needs. For example, when working with schools, they develop a design plan that meets the needs for the school and then they provide a guaranteed bid, months or years before construction will begin. This allows schools to secure community funding by improving the perception of fiscal responsibility of the school district and guaranteeing the community that the project will operate within the approved budget. This business model requires that both the client and corporation act as interdependent agents, resulting in new ways of building schools and financing bond issues.

Third, World Partners does more than provide design and construction services to it clients; it also works to teach clients to improve their own practices. World Partner's behaviors and strategies are congruent with their mission statement that values community well-being on an equal ground with corporate fiscal success. Key managers state "we don't necessarily just do what we do because we think its good business, we also realize that training and teaching people how to take care of the community is critical. We carry that philosophy and concern into the community via our professional and personal lives." The organization emphasizes a teaching relationship with its clients, "A lot of our clients take some of the things we do well and apply it to their own businesses. We aim to influence our clients and the community." Notice here that this corporation does not place boundaries between personal and professional values nor between corporate and community well-being.

Fourth, the firm encourages its employees to invest their personal funds in client projects to advance productivity and their connectedness and commitment to both the organization and the place ${ }^{3}$. Employee participation in client projects enables employees to interact with clients on a more personal level, distinguishing them as partners and agents of change. Employees describe the firm's culture as pro-learning and pro-relationship. As one employee stated, "Employees can say I own a piece of that building, thus creating a positive attachment to the organization. And that is what makes 
this organization an important part of the community." Whereas, traditionally, employees are able only to invest in corporate stock, this business practice allows employees to invest in both the company and the community. This mutually beneficial investment model is based on the organization's conception that the company's well-being is inseparable from the well-being of place.

Finally, World Partners demonstrates concern for the well-being of all three spheres of place, social, natural, and material. The organization encourages employees to contribute in ways that are unique and special to them. The owner states "If an employee wants to volunteer for junior achievement which takes an hour or two during the work day, that's hard, but if their work is done then we encourage them to find ways to participate in the community." Allowing employees to contribute to local organizations during the work day results in tangible benefit to the social relations realm of place. Although, World Partner's primary intention is to transform the built environment in ways that contribute to community well-being, it also recognizes the importance of protecting the natural environment. Building designs include the use of natural landscaping, green building materials, maximizing energy efficiency, compatibility with local history and architecture (Thomas, 2004). It voluntarily monitors the impact its construction has on local ecology and turns down projects that violate their principals or may negatively impact the natural environment (Thomas, 2004). Rather than being motivated by laws and regulations to protect the natural environment, World Partners is motivated by their own desire to transform place and their industry in positive ways, as reflected in the mission statement.

\section{Contributive Organization}

Contributive organizations view themselves as a contributing member of a network of business people and community leaders who share a common ideology. Their identity as a local contributor is affirmed by engaging in local organizations, fundraising, and philanthropy that give back to place (Schneider, Brief, and Guzzo, 1996; Chaskin, Brown, Venkatesh and Vidal, 2001). In contrast to transformational organizations that view themselves as responsible for the well-being of place, a contributive organization views itself as a contributor to the well-being of place. The organizational culture is focused on "giving back" and conforming to local norms and values.

Contributive organizations value place first for its social relationships and second for economic opportunities and potential for business growth. The natural world is just the setting or geographic location of their business. These organizations need a place that needs them; part of the value of place is that it provides a niche for these organizations to simultaneously prosper and give back to place. They practice an integrative strategy that cultivates and promotes its role as a key player/contributor in the community. Contributive organizations value each of the three realms of place for what that realm provides for the community and the organization; nature for its natural resources that make the place unique: material environment for its community's infrastructure and access to organizations; and the social realm for the community's network of individuals and businesses that facilitate its philanthropic and social membership activities. 
Corbin Company. The Corbin Company is a small electric supply company that employs 20 employees. They sell and install electric support systems to large commercial users. This company is typical of contributive organizations because of its value of "giving back" to the community. The owner of this small business states that, "the purpose of my business and any business is to simply 'make life better'. The only reason that we exist as a business is to improve life." "Making life better" is the official mission statement of this small electrical company.

This company strives to make life better for their clients and community residents in many ways. First, it provides free electrical workshops on how to bring your home up to code and reduce electrical hazards in the home. The owner of the company also conducts seminars for electricians on best practices, consults with local government officials on improving code standards, and provides workshops to other business owners on ethical business practices.

Second, when working with clients, Corbin Company strives to ensure that their installations are designed for the greatest benefit of the client, community, and environment. As part of the bid, Corbin Company provides free consulting on how to develop the most efficient design, whether or not it receives the contract. The owner of the company is more focused on providing safe, state-of-the-art products than on submitting the lowest bid. He prefers to offer only the highest quality design and service, rather than the most competitive bid. Through his business practices, he places a higher value on the client's long-term benefit than on the company's financial gain. In some cases Corbin Company has reduced its margins in order to provide the client with the highest long-term benefit. In every bid, the owner reduces his margins in order to install products that improve efficiency and reduce environmental impacts but are more costly. This business practice is driven by the owner's commitment to "making life better", which he sees as including reducing environmental impacts, energy consumption, and the client's long-term costs.

Third, Corbin Company gives back to the community in more philanthropic avenues as well. The company regularly does pro-bono work, providing free labor (design and electric installation) for community projects including schools, low income housing, and a health clinic for low income women. The owner and employees sit on community boards (Chamber of Commerce, Hospital District) are members of philanthropic organizations (Kiwanis, Lions Club), and contribute to local community projects.

The organization emphasizes networking, conducting moral and ethical business practices, as the key to making life better. The organization values place for its networking or connections to others and the spirituality of those connections for the owner. The organization represents and promotes strong ethical business practices. The owner believes in teaching its employees and customers the value of living life in ways that contribute and benefit those with whom they deal. Everything the Corbin Company does from consulting with clients, to pro-bono work, to community philanthropy is driven by the owner's philosophy: 
I think you are the place that you are located as a company. That's why we have businesses to improve people's lives, to improve the customer's life. And in turn if

you improve in life for people, you improve on the living environment, the city; I think it kind of goes hand in hand.

Corbin Company makes its strongest contributions to the social relationships realm of place through regular donations to philanthropic organizations and existing charitable projects. Although this company makes substantial contributions to community wellbeing and existing initiatives, it does not seek to improve or help those organizations grow and change. Corbin Company improves the material environment by going beyond compliance with existing codes to working with local government to improve building codes, by using the most long-lasting and energy efficient technology in their installations, and by inspecting and monitoring the compliance and performance of electrical systems across the community. Both transformational and contributive organizations share a commitment to sustainability and well-being of place.

They differ in that transformational organizations intend to be change agents while contributive organizations view themselves more as stewards, maintaining quality of life without a vision for change.

\section{Contingent Organization}

Contingent organizations view themselves as disassociated and autonomous agents. They narrowly define CSR as obeying existing laws, regulations, and ethical codes, but they make a concerted effort to act accordingly. Rather than viewing themselves as interdependent with place (transformational) or key members of place (contributive), they view themselves as control agents. They operate from a managerial point of view; the organization's culture is highly structured and values the processes or systems. The contingent organization practices a separatist strategy that centers on a plan that distinguishes the organization in terms of its economic power. Contingent organizations value each of the three realms of place for what that realm provides for the company; nature for it ability attract and retain employees as well natural resources used by the company; the material environment for the community's infrastructure; and the social realm for its labor force. They practice philanthropy only as a method for advancing their own causes, not out of any intrinsic commitment to place, and their principle contribution is their economic contribution and adherence to laws and regulations.

Benson Industry. Benson Industry is a globally recognized manufacturer with a reputation for quality products. The organization was recruited to its current location in the 1970s and currently employs over 2000 . The firm prefers to be seen as the "employer of choice" and as a "good corporate citizen" which the firm views as a key strategy in advancing its image and brand. This firm exemplifies the contingent type through its inward-looking view or attitude that is geared toward protecting its brand reputation and achieving business goals. Any discussion of corporate social responsibility and local communities is secondary to its profit motives. 
First, Benson Industry typifies contingent organizations because it value places for the opportunities available there. Benson chose its current location because of the accessibility to land, natural resources, and distribution networks. Local governments offered Benson tax incentives and financing for improving local infrastructure. The local community also offered a low-cost, non-unionized labor pool. Benson located where it did, not because of a desire to contribute to the local place, but because of the opportunities that the place offered. This perspective that place is a commodity, chosen for the advantages it offers the company, is characteristic of the contingent organization.

Second, this company contributes to the local place in order meet their own strategic goals. They have a "community committee", comprised of business members from the surrounding community, whose task is to identify and anticipate areas of conflict between the organization and the place in which they do business. For example, this committee is asked if there are any complaints being expressed in the local community that might impact the corporate image or any new regulations that might impact the company's business. This company regularly scans their business environment to identify threats and opportunities and then makes local investments and contributions based on their potential to reduce threats or exploit an opportunity. For example, the local county proposed to increase the mill levy and the company fought that change because it would have reduced their profit.

This company supports local non-profit organizations not because it values giving back to the community or improving the lives of others, but rather because of the societal expectation that corporations contribute to local non-profit and philanthropic organizations. Both the corporation and employees contribute to United Way every year because it meets a minimum expectation to make a contribution to the local place and because association with a reputable philanthropic organization facilitates good public relations and favorable publicity. Benson gives back to the community, not because they are invested in improving the local place, but because it is good for business. One manager stated, "We have to have that positive reputation as a solid citizen. Otherwise people aren't going to buy your products; people aren't going to come to work for you." Benson views their philanthropy and involvement as a two-way relationship. "It's not just a one-sided thing, but it's what the community needs as well as what benefits to the firm."

Third, this company identifies their own corporate social responsibility in much more limited terms than the two we have already discussed. The corporation identifies CSR as including a) obeying local, federal, and international laws, b) upholding ethical standards, c) respecting worker's rights, d) environmental responsibility, and e) philanthropy that reflects its corporate goals. Rather than intending to transform the local community or help places grow and improve quality of life, Benson intends nothing more than operating in a legal and ethical manner, and making philanthropic contributions that support its own goals. 
Benson's impact on the three realms of place is governed by their primary concern with meeting corporate goals. Although Benson complies with labor laws and environmental regulations which impact all three realms of place, none of their actions are intended to have a specific benefit to any realm of place. To the degree that contingent organizations, who strive only to meet the letter of the law, are able to pollute the environment or take advantage of workers without violating environmental or labor regulations, they may have a negative impact on one or more realms of place, whereas both transformational and contributive organizations look for ways not only to minimize their environmental impact but also improve the social realm of place as well . Benson's contributions to local philanthropic organizations are designed to satisfy to most basic expectations for corporate giving at the local level. In the material realm, Benson seeks to minimize their economic contribution to wages and the local tax base. Unlike transformational and contributive organizations which may reduce their own profits in order to deliver a superior product to the client and community, contingent organizations like Benson, seek first and foremost to maximize their profit, though within strict legal and ethical bounds. Benson's corporate impact on the three realms of place is always contingent on first meeting corporate goals and avoiding risk. Their contributions to place in the three realms are limited by the strength of laws, regulations, and ethical standards.

\section{Exploitative Organizations}

Exploitative organizations view themselves as occupants of place. They are isolated with respect to the traditions and values of the community. These organizations argue for corporate citizenship where organizations are afforded the rights and legal protections typically afforded only to individual citizens (Vogel, 2005). It plans and organizes its control over place. Cost effectiveness and short term financial progress trumps any local need (Thomas, 2004). Exploitative organizations value place as a commodity where each of the three realms of place is valued for what the realm can provide for the organization. They are active users of the economic, cultural, social, and political resources, which they utilize to their greatest economic benefit (Sagoff, 1996; Rodman, 1992; Entrikin, 2000).

The exploitative firm practices a separatist strategy. Their mission to maximize profit determines the exploitative organizations strategy, to deliberately target certain places for the potential to extract resources without accountability or regard for the risks posed to local population. While some exploitative organizations employ locals and deal with local suppliers, in the end, these organizations are not invested in ways that contribute to place well-being. Exploitative organizations are likely to leave a place once they have determined they don't fit or the return is not as lucrative as originally anticipated.

Centro Associates. Centro Associates is a commercial and residential real estate company owned by its employees. It has been operating for over 30 years and employees over 200 sales agents. In its operating region, this agency holds about $25 \%$ of the real estate listings, and claims to participate in the largest proportion of real estate transactions of any agency. Centro Associates has branded their agency as the top 
real estate company in the region. Centro Associates exemplifies the exploitive type because they use their market dominance to maximize their revenues at the expense of its clients, other real estate firms, and the local housing market.

First, Centro Associates distinguishes itself as an exploitive company through its own marketing. It consistently identifies itself as a market leader, but makes no claims about its contributions to place. This company has no mission statement or articulated vision, and makes no mention of corporate responsibility in its promotional materials. Its only value statement espouses the importance of being a market leader through alignment of individual and organizational goals. Unlike the transformational organization, World Partners, which endeavors to improve and transform the local community as it grows and learns as a company, Centro Associates has only inward-looking goals focused on financial dominance. In contrast to other real estate agencies in the region, who describe good agents as those who take seriously their fiduciary responsibility to their clients, are good listeners, true partners, and advocates (Coldwell Banker, 2006; Remax, 2006), Centro Associates describes agents as primarily transaction specialists whose responsibility is information provision. What is most telling about this agency's values and goals is the lack of any discussion of their responsibility to their clients, to the larger place, or to legal and ethical standards. Exploitive companies stand out from the other types because of their self-focused mission and values statements. When describing themselves, Centro Associates describes its agents as leaders, highly trained, and having access to the latest technology. In contrast, its competitors emphasize the responsibility of agents to represent the personal, financial, and legal interests of their clients (Coldwell Banker, 2006; Remax, 2006).

These organization-focused goals and values are apparent in the activities of Centro Associates. This company has exploited the communities in which it operates by treating the local real estate market as a commodity to be exploited for its own financial gain, with little concern or responsibility for individual clients or the overall well-being of the local housing market and economy. For example, Centro Associates employs three strategies that take advantage of the local market, clients, and neglect established ethical principals of their industry. First, it encourages its agents to pursue listings and represent buyers in the top $50^{\text {th }}$ percentile of the local housing market, while discouraging working with buyers and sellers in the lower half of the market. Their listings comprise $25 \%$ of the total market, but represent less than $20 \%$ of the market below the median versus over $30 \%$ of the market above the median, and less than $10 \%$ of the market below $\$ 150,000$ versus over $40 \%$ of the market over $\$ 600,000$ (Multiple Listing Service, 2006). This practice serves the financial goals of individual agents and the company while neglecting property owners in the lower half of the market.

Second, Centro Associates agents are known to routinely outbid agents from other agencies when vying for listings. Evidence of this can be seen in a market analysis of local listings where properties listed by Centro Associates are consistently at top of the price range for comparable properties (Multiple Listing Service, 2006). Third, they use their market dominance to pressure buyers they represent into purchasing over-priced listings held by other Centro agents. One way they do this is by taking advantage of a 
tight housing market—offering home buyers "the unique chance" to make the first bid on a property listed by another agent in their company before it is officially listed and then encouraging them to offer the listing price immediately. During periods of high housing demand, this tactic was highly successful and gave the appearance of representing the buyer's interests by helping them to get a contract in a tight market. This practice represents the interests of both agents and the company by maximizing their commission and reducing the time on the market, but neglects the financial and other interests of the buyer (Leavitt \& Dubner, 2005). Combined, these three strategies allowed Centro Associates to increase and maintain their market dominance and maximize company profits. These practices are exploitive because they neglect whole segments of the market, rely on unethical business practices, undercut competitors, and are a disservice to the financial interests of clients, other homebuyers, and the industry. Centro Associates' webpage has no mention or discussion of social responsibility. The "community involvement" page on Centro Associates web site includes only a list of philanthropic organizations to which it has made contributions. A careful look at this listing reveals that their donations are targeted to groups and organizations that include likely high-end clients, arts councils and symphony orchestras, and those who can assist them or favor their business in some way. Notably, they do not list low-income service organizations, such as Habitat for Humanity, as regular beneficiaries.

\section{Comparison of Four Types of Place Builders}

Each of the four types stands out from the others in their perspectives on place and the consequences of their actions. Transformational organizations orchestrate their contributions in ways that transform themselves and place. As agents of change, they are distinguished from other organizations in that they view place in a holistic manner in which all three realms are interactive and interdependent. Consequently, the business practices of transformational organizations contribute to place well-being through learning and teaching in partnership with clients. The other organization that operates from an interdependent perspective, contributive, also engages in business practices that benefit the community, however in a slightly different manner from transformational types. The contributive organizations' foci are on satisfying their need to "give back". They are not motivated to change themselves or place, but rather to fit in as an advocate and participant in worthwhile community activities. As a result, contributive organizations add to the community capacity to address local concerns by being persistent contributors.

In contrast to the interdependent agents, the organizations with an independent perspective engage in business practices that restrict their contributions to place wellbeing because priority is made to fiscal success. The contingent organization contributes primarily in manners that garner some return or benefit to the organization. Unlike the transformational and contributive organizations, the contingent organization respects local laws, regulations, and ethical codes without pro-actively investing it resources or assets. The degree to which their business practices enhance or damage place is determined by the nature and scope of laws, ethical codes, and regulations to which they comply. In comparison, exploitative organizations are more than indifferent 
to the impact of their actions; they may go so far as to intentionally create harm and avoid responsibility for their actions. The exploitative organization has little regard for place and views the realms as resources or commodities (Logan \& Molotch, 1983; Cross, 2001). They are absentee organizations in the sense that while they may occupy a place they are not engaged or invested in place. Additionally, these are the organizations that are the greatest threat to the well-being of all three realms of place.

\section{Discussion and Conclusion}

The relationship between place and organizations is important for understanding the role and social responsibilities of an organization within its community (Kemmis, 1990). Bio-regionalists like Gary Snyder (1995) suggest that organizations, as well as all other agents, should consider their responsibility to the well being of the environment and the people that live in a place. Snyder perceived the organization as located in a place in which it either adds or detracts from the "great landscape." Geographer Robert Sack (1997) argues similarly that all actions in place have a moral aspect:

The geographic also extends the realm of the moral. Almost all abstract moral precepts focus on our relations to other human beings. But geography draws attention to the fact that this in an incomplete conception of our responsibilities. Real actions, awareness, and moral concerns in place and space inevitably draw nature into the picture. This is because real actions and real places themselves are integrations of nature and culture (or, more precisely, of nature, social relations, and meaning). When we construct cities, schools, factories, and streets we are removing many facts of nature while retaining and controlling others... Constructing and maintaining any place require decisions about whether particular natural or cultural elements should exist here rather than there, or exist at all. Each and every decision we make about places to live, work, and visit engages us in this calculus, balancing our interest in nature and culture. Place helps make us aware that moral concern is not bounded by the neat conventions of academic disciplines and, in particular, that the social world is not divorced from the natural, but intimately linked to it at every geographic scale, from home to world. This role of place increases our understanding of these virtues and of our moral role as geographical agents. (p. 22)

If bio-regionalists and others are right about place, its construction, and the role of agents, then advancing the notion of organizations as place building agents takes on new significance regarding the strategic value of organizations to the communities or places. Not only do social and physical scientists mistakenly consider their subject matter as though it is not only placeless but also spaceless (Agnew, 1993; Sack, 1997). The same is true of corporations; many of them conceptualize their activities as being placeless and spaceless. Only those organizations who conceptualize themselves as belonging to a particular place develop an organizational culture which understands that their responsibilities expand beyond the placeless and spaceless financial interests of the shareholders. 
The typology we have presented here illustrates how one type of organization, the corporation, contributes to the social construction of place through its mission, priorities, value of place, and subsequent behaviors. Although our illustrative examples and narrative describe corporations, the four types of agents might also be applied to other types of organizations including governmental agencies and not-for-profit organizations. While the basic mission of governments and most non-profits is typically defined as service to a geographic space or shared interest community rather than financial profit, this does not preclude them from adopting practices that exploit or endanger one or more realms of place. In addition to expanding the conception of CSR, the typology we have presented might also be used to examine the social responsibility and comprehensive impact of any organization on the place in which it operates. Implications for Corporations \& Communities

The traditional model of CSR is limited in scope and influence. In contrast, we have argued for a more expansive perspective which examines not only a corporation's philanthropic actions and their compliance to laws and regulations but which also examines their place values, their mission, and the potential of their business practices to enhance or diminish place well-being. We have described four types of organizations, each of which influences the social construction of place in unique ways. Keeping these four types in mind, we ask, "what are the implications for place and organizations if CSR is measured by how corporations conceptualize themselves and act as agents in the construction of places?" If an organization examines where they fit in the typology, then our model provides a framework for considering first whether conceptualizing themselves as an interdependent or independent agent is serving their true goals. Second, the model (Figure 2) might provoke an organization to examine the balance between their commitments to place well-being and fiscal success.

The model we have proposed also offers a new framework for thinking about what types of organizations communities are attracting and recruiting. For cities, towns, and other groups working to attract organizations, this typology offers a new model for considering the role of an organization as an agent and assessing its behavior and strategies in building place. Second, the model (Figure 2) might provoke municipalities and/or chambers of commerce to examine whether the firms they are attracting share their commitments to place well-being and economic development. Governing bodies should consider whether the incentives they offer produce not just the desired return, but attract a partner that can help them build and transform their place in ways aligned with current community goals. The governing boards of cities, counties, business districts, and chambers of commerce might ask, "Do these organizations have the values and vision for expanding our community's capacity while creating a competitive advantage to the organization?" We have provided a typology that can be useful in assessing the best fitting organization. While its one thing to attract the best fitting firm; it's another to build a sustainable partnership. Perhaps cities, counties, and business districts should also ask, "What are the costs of attracting, and retaining the wrong organization." The benefits of attracting organizations that help build the economic well-being of place are obvious, but assessing the degree to which a corporation might make minimal contributions to the three realms of place or engage in behaviors that are destructive 
versus constructive (exploit local labor, pollute the natural environment, value profits over long-term sustainability, etc.) should be considered in balance with economic contributions. The typology we present here provides a starting point for examining the breadth of an organizations priorities and the degree to which their regular business practices are likely to contribute to or detract from the three realms of place. Identifying and attracting organizations that will make tangible contributions and consider the impact of their actions on all three realms of place will provide places with legacies that last long after the initial economic benefits have been realized.

\section{New Directions for Research}

The typology we presented is a step in the direction of building a coherent theory of how organizations construct place and poses new questions about the role of corporations in relation to places. We have shown that corporate identities, missions, and practices are all tied to how corporations influence the well-being of place. Future work is needed to create a viable device or instrument to measure and validate the typology we have proposed. If a tool were developed to accurately type organizations, then researchers could examine other questions, including: What predictors could we use to identify these organizations? What specific strategies and behaviors are associated with each type? Taking up Gan's call to examine the causal relationships between organizations and place elicits a variety of new questions posed by the application of our typology: What are the advantages of a corporation acting as one type versus another? Is size of company or industry associated with greater success as one kind of agent versus another? Does acting as one type of agent versus another create a competitive advantage? Are the types of agents associated with size of corporation, industry, region, profitability, and products/services? Can organizations be more efficient and effective when they know how to define place and their role in the community? Finally, can these types provide new insights and the basis of a metric for defining and measuring CSR, as both a predictor and dependent variable?

Further, a theoretical understanding of how place is constructed can advance the field of community management and economic development by advancing a new way of thinking about what types of firms that are likely to advance the community's interests, solve collective problems and improve or maintain the well-being of community (Chaskin, Brown, Venkatesh, and Vidal, 2001). A theoretical understanding of how organizations contribute to the construction of place would benefit from the work of economists, geographers, sociologists as well as management theorists. Perhaps even more important is the contribution various social scientists might contribute to improving the economic, environmental, and social well-being of places through a more sophisticated examination of the relationship between place well-being and organizational missions, strategies, and practices. This examination of relationships is critical as it helps identify best fitting organizations and provides a new model for how communities can assess and even predict an organization's contribution. This kind of examination goes beyond the typical economic assessment that counties, 
municipalities, chambers of commerce and other governing bodies typically employ, which focus on primary jobs and building industry clusters.

\section{References}

Agnew, J. (1993). Representing Space: Space, Scale and Culture in Social Science. In J. Duncan \& D. Ley (Eds.), Place/Culture/Representation (pp. 251-271). New York: Routledge.

Agnew, J. A. (1987). Place and politics. Boston: Allen \& Unwin.

Altman, I., \& Low, S. (1992). (Eds.). Place Attachment (Vol. 12). New York and London: Plenum Press.

Alvesson, Mats. (1990). On the popularity of organizational culture. Acts Sociologica, 33, 1:31-49.

Alvesson, Mats and Berg, Per Olof. (1992). Corporate culture and organizational symbolism: An overview. Walter de Gruyter: New York .

Anderson, J.W. (1989). Corporate social responsibility: Guidelines for top management Quorum Books: New York

Black, L. D. \& Hartel, C.E.J. (2004). The five capabilities of socially responsible companies. Journal of Public Affairs, 4(2): 125-144.

Blumer, H. (1969). Symbolic interactionism: Perspective and method. Los Angles: University of California Press.

Buttimer, A., \& Seamon, D. (1980). (Eds.). Human experience of space and place. New York: Martins.

Butz, D., \& Eyles, J. (1997). Reconceptualizing Sense of Place: Social Relations, Ideology and Ecology. Geografiska Annaler, Series B, Human Geography, 79: 1-25.

Chaskin, R. J., Brown, P., Venkatesh, S. \& Vidal, A. (2001). Building community Capacity. New York: Aldine de Gruyter.

Coldwell Banker web site. Retrieved August 23, 2006, from http://coldwellbanker.feedroom.com.

Cooper, S. (2004). Corporate social performance: A stakeholder approach. Burlington, VT.

Creswell, T. (2004). Place: a short introduction. Malden, MA: Blackewell Publishing. 
Cross, J. E. (2001). Disruptions in community attachment: The social-psychological impacts of rapid economic \& demographic change. Paper presented at the $11^{\text {th }}$ Headwater's Conference, Gunnison, CO.

Dellheim, C. (1986). Business in time: The historian and corporate culture. The Public Historian, 8: 9-22.

Denison, D.R. (1996). What is the difference between organizational culture and organizational climate? A native's point of view on a decade of paradigm wars. The Academy of Management Review, 21: 619-65.

Dennis, L.H., \& Herring, L. (1999). Corporate relocation takes it toll on society. Workforce. 78(2):121-132.

Entrikin, J.N. 2000. The betweeness of place: Towards geography of modernity. New York: Routledge.

Etzioni, Amitai. (1993). The Spirit of Community: rights, responsibilities, and the communitarian agenda. New York: Crown Publishers.

Etzioni, Amitai. (1998). "The responsive communitarian platform: Rights and responsibilites". In Etzioni, A. (Ed.), The Essential Communitarian Reader (pp. xxvxxxix). New York: Rowman \& Littlefield Publishers, Inc.

Folkerts, H., \& Weijers, R. (2004). De winst zit in de opbremgst, naar een duurzame ontwikkeling, in: Mastering Strategy, Het Finacncieele Dagblad.

Fussler, C.A. Cramer \& van de Vegt, S. (2004). Raising the bar, creating value with the United Nations Global Compact. Sheffield: Greenleaf Publishing.

Gans, H. J. (2002). The sociology of space: a use-centered view. City and Community, 1(4): 329-339.

Geertz, C. (1973). The interpretation of cultures. New York: Basic Books.

Geertz, C. (1983). Local knowledge. New York: Basic Books.

Gieryn, T. F. (2000). A Space for Place in Sociology. Annu. Rev. Social., 26:463-496.

Guion, R. (1973). A note on organizational climate. Organizational behavior and human performance 9:120-125.

Gustafson, P. 2005. Meanings of Place: Everyday Experience and Theoretical Conceptualizations. Journal of Environmental Psychology, 21, 5-16. 
Hatch, M.J. (1993). The dynamics of organizational culture. The academy of management review, 18(4):657-693.

Hamad, G. (1974). Strategy as revolution. Harvard business review, July: 24-30.

Hopkins, M. 1999. The planetary bargain: corporate social responsibility comes of age. St martins press: New York.

Hudson, R. (2001). Producing places. New York: The Guilford Press.

James, L., \& Jones, A. (1974). Organizational climate: A review of theory and research. Psychology Bulletin. 18: 1096-1112.

Jonker, J., \& de Witte, M. (2006). Management Models for Corporate Social Responsibility. (Eds.). Berlin: Springer.

Kaufman, H.F. (1959). Toward an interactional conception of community. Social Forces, 38(1): 8-17.

Kemmis, D. (1990). Community and the politics of place. Norman, OK.: University of Oklahoma Press.

Kotler, P. \& Lee, N. (2005). Corporate social responsibility: Doing the most good for your company and your cause. Hoboken, N.J.: Wiley.

Kotter, J.P. \& Heskett, J. L. (1992). Corporate culture and performance. New York: The Free Press.

Langtry, B. (1994). Stakeholders and the moral responsibilities of business. Business Ethics Quarterly, 4 (4): 431-441.

Levitt, S. D. \& Dubner, S. J. (2005). Freakonomics: A Rogue Economist Explores the Hidden Side of Everything. New York: Harper Collins Publishers.

Logan, J. R. \& Molotch, H. L. (1983). Urban Fortunes: The Political Economy of Place. Berkeley, CA: University of California Press.

May, L. (1983). Vicarious agency and corporate responsibility. Philosophical Studies. 43: $69-82$.

McClenahen, J. (2005). Defining social responsibility. Manufacturing and Society, March: 64-66.

Morgan, G. (1997). Images of organization. $\left(2^{\text {nd }} E d\right)$ Thousand Oaks: Sage. 
Multiple Listing Service web site. Retrieved August 23, 2006, from http://www.mls.com. http://www.remax.com/residential/real_estate_101/buying_a_home/index.aspx;

Newell, P. (2005). Citizenship, accountability and community: The limits of the agenda. International Affairs. 81 (3): 541-537.

Ouchi, W.G., \& Wilkins, A.L. (1985). Organizational culture. Annual Review of Sociology. 11: 457-483.

RE/MAX web site. Retrieved August 23, 2006, from http://www.remax.com/residential/real_estate_101/buying_a_home/index.aspx;

Rodman, M. (1992). Empowering place: Multilocality and multivocality. American Anthropologist, New series, 94(3): 640-656.

Sack, R. (1997). Homo Geographicus. Baltimore, MD: The Johns Hopkins University Press.

Sack, R.D. (1988). The consumer's world: Place as context. Annals of the Association of American Geographers, 78(4): 642-664.

Sagoff, M. (1996). Values and preferences. Ethics, 2: 301-316.

Sauer, C. (1925). The morphology of landscape. Berkeley: University of California Publications in Geography. 2:19-54.

Savitz, A.W., \& Weber, K. (2006). The triple bottom line: How today's best run companies are achieving economic, social, and environmental success-and you can too. San Francisco: Jossey-Bass.

Schneider, B., Brief, A.P., \& Guzzo, R.A. (1996). Creating a climate and culture for sustainable organizational change. Organizational Dynamics. Spring: 7- 18.

Schein, E.H. (1992). Organizational culture and leadership. San Francisco: JosseyBass

Schoenberger, E. (1997). The cultural crisis of the firm. Cambridge: Blackwell

Selznick, P. (1995). Thinking about community: Ten theses. Society, 32: 33-37.

Senge, P. (1990). The fifth discipline: The art and practice of the learning organization. New York: Currency Doubleday.

Smircich, L. (1983). Concepts of culture and organizational analysis. Administrative Science Quarterly, 28 (3): 339 -54. 
Smith, C. (1994). The new corporate philanthropy . Harvard Business Review, 72, 3.

Snyder, G. (1995). A place in space: Ethics, aesthetics, and watersheds. Washington D.C.: Publishers Group West.

Thomas, D.F. (2004). Toward an understanding of organization place building in communities. Unpublished doctoral dissertation, Colorado State University, Fort Collins, Co.

Tuan, Yi-Fu. (1977). Space and place: The perspective of experience. Minneapolis: University of Minnesota Press.

Vogel, D. (2005). The market for value: The potential and limits of corporate social responsibility. Brookings Institution Press: Washington D.C

Vogel, D. (2005). The low value of virtue. Harvard Business Review, June: 26.

Weick, K.E. (1995). Sensemaking in organizations. Thousand Oaks: Sage.

Werlen, B. (1993). Society, Action, and Space: An Alternative Human Geography. London: Routledge.

Williams, R. (1989). Resources of Hope: Culture, democracy, socialism. New York: Verso Publishers.

Wright, S. (1994). (Eds.). Anthropology of organizations. New York: Routledge.

Zelinsky, W. (1992). Cultural geography of the United States. Englewood Cliffs, NJ: Prentice Hall.

\section{NOTES}

${ }^{1}$ We recognize that the natural world has been altered to varying degrees by human activity; however, we maintain that nature as a realm of place is distinct from the built environment and other man-made aspects of space.

${ }^{2}$ Data for these company profiles were collected by the first author for his doctoral dissertation. Respondents were informed of the basic goals of the research, and each signed consent forms guaranteeing their confidentiality. Interviews of company employees were approved by company managers and in some cases, corporate headquarters. Names of companies and other details have been changed to ensure the anonymity of respondent.

${ }^{3}$ This practice raises both legal and ethical concerns, and the authors have heard conflicting viewpoints on the matter from employees. However, World Partners continues to believe that investing in projects enhances the value of those projects. 